$\begin{array}{lll}\text { Türkiye Tarımsal Araştırmalar Dergisi } & \text { Turk J Agric Res } \\ \text { 2017, 4(1): 96-102 } & \text { C TUTAD } \\ \text { dergipark.gov.tr/tutad } & \text { ISSN: 2148-2306 } \\ \text { e-ISSN: 2528-858X } & \text { doi: 10.19159/tutad.300725 }\end{array}$

\title{
Azot ve Kükürt Beslenmesinin Buğday Tanesine Çinko ve Demir Taşınmasındaki Rolü
}

\author{
Hatun BARUT ${ }^{*}$, Sait AYKANAT ${ }^{1}$, Selim EKER ${ }^{2}$ \\ ${ }^{1}$ Doğu Akdeniz Tarımsal Araştırma Enstitüsü Müdürlüğ̈̈, Adana, TÜRKİYE \\ ${ }^{2}$ Çukurova Üniversitesi, Toprak Bilimi ve Bitki Besleme Bölümü, Adana, TÜRKIYE
}

\begin{abstract}
Geliş Tarihi/Received: 24.10 .2016
Kabul Tarihi/Accepted: 31.01 .2017

"Sorumlu Yazar/Corresponding author: hatun.barut@tarim.gov.tr

Özet: Son yıllarda yapılan araştırma sonuçları, tahıl tanelerinin mineral element (çinko ve demir) konsantrasyonları bakımından fakir olduğunu ortaya koymuştur. $\mathrm{Bu}$ nedenle tahılların beslenme kalitesinin arttırılması gerekmektedir. Buğdayda tane verimi ve protein konsantrasyonuna, azot ve kükürt beslenmesinin önemli etki yaptığı bilinmektedir. Bazı fiziksel ve moleküler mekanizmalardan dolayı bitkilerin azot beslenme statüleri çinko ve demir alımlarını ve birikimini etkileyen en önemli kompenent olduğu gösterilmektedir. Buğdayın kükürt ihtiyacı azota göre azdır. Ancak, kükürt eksikliğinde protein olmayan azotlu bileşikler (asparagine, glutamine) birikmekte, kükürt içeren amino asitlerin (sistein, methionine) sentezi ve tanedeki birikimleri azalmaktadır. Buğday tanesinin çinko (ve demir) içeriğinin arttırılması çabaları; çinkonun kök bölgesinden absorbsiyonu, kökten bitki dokularına taşınması, floemde taşınımı, çinkonun bitkinin vejetatif dokusundan gelişmekte olan tohuma taşınması ve tohumda çinkonun depolanması gibi, süreçlerdeki bilgi eksikliğinden dolayı engellenmektedir. Literatürde artan kanıtlar, yukarıda sayılan faktörlerin azotlu gübreleme veya bitkinin azo metabolizması tarafindan etkilendiğini işaret etmektedir. Son yıllarda yapılan araştırmalarda, tanenin çinko ve demir konsantrasyonunun, azot uygulamasıyla arttırılabileceği ve çinko ve azot uygulamalarının makarnalık buğdayın tane çinko konsantrasyonunun arttırılmasında sinerjik etki yaptığı belirtilmiștir. Çinkonun floem yoluyla taneye taşınabilmesi için, kükürt içeren amino asitlerle ligand oluşturması gerektiği belirtilmiştir. Bu çalışmada, buğday tanesinde çinko ve demir birikiminde, azot ve kükürt beslenmesinin önemi vurgulanmıştır.
\end{abstract}

Anahtar Kelimeler: Buğday, azot, kükürt, çinko, demir, kalite

\section{The Role of Nitrogen and Sulphur Nutrition on Zinc and Iron Transport to Wheat Grain}

\begin{abstract}
Research results in recent years, revealed that cereal grains are low in mineral element (zinc and iron) concentrations. Therefore, improving the quality of nutrition is required. Significant effects of nitrogen and sulphur nutrition on grain yield and protein concentration of wheat were reported. Nitrogen nutrition of plants appears to be a critical component for an effective bio-fortification of food crops with $\mathrm{Zn}$ and $\mathrm{Fe}$ due to several physiological and molecular mechanisms. The sulphur requirement of wheat is lower than nitrogen. However, in case of sulphur deficiency, nitrogenous compounds (asparagines, glutamine) are accumulated, S-containing amino acid (sistein, methionine) synthesis and accumulation decreased in grain. Efforts to increase the Zn concentration (and Fe) in wheat grain are root uptake, root-toshoot transport, phloem loading, remobilization of $\mathrm{Zn}$ from source tissues into developing seeds and seed deposition of $\mathrm{Zn}$. Researches provide increasing evidences about possible effects of nitrogenous fertilization on plant nitrogen mechanisms of the above mentioned factors. Recently, it has been reported that grain concentration of $\mathrm{Zn}$ and Fe can be enhanced by increasing the nitrogen $(\mathrm{N})$ supply and $\mathrm{N}$ and $\mathrm{Zn}$ applications have a synergistic effect on grain $\mathrm{Zn}$ concentration of durum wheat.ZZinc needs to form ligand with S-containing amino acids in order to be carried by phloem. In this study, the importance of nitrogen and sulfur nutrition on zinc and iron accumulation in the grain of wheat has emphasized.
\end{abstract}

Keywords: Wheat, nitrogen, sulphur, zinc, iron, quality 


\section{Giriş}

Çinko ve diğer mikro element eksikliklerinin özellikle gelişmekte olan ülkelerde çok ileri boyutlarda olduğu bilinmektedir. Buğday, gelişmekte olan birçok ülkede en önemli temel enerji kaynağıdır. Ancak söz konusu buğdayın tanesinin çinko $(\mathrm{Zn})$ konsantrasyonu (genellikle 25-30 mg kg-1), insanların sağlıklı beslenebilmesi için ihtiyaç duyulan veya tavsiye edilen seviyeden çok düşüktür (Erdal ve ark., 2002; Çakmak, 2008). Türkiye, İran, Hindistan ve Avusturalya'daki Zn eksikliği olan topraklarda gözlemlendiği gibi, buğday $\mathrm{Zn}$ gübrelemesi yapılmaksızın $\mathrm{Zn}$ yönünden zayıf topraklarda yetiştirildiğinde elde edilen tanelerin $\mathrm{Zn}$ konsantrasyonu $10-15 \mathrm{mg} \mathrm{kg}{ }^{-1}$ seviyesinden daha düşük düzeylere inebilmektedir (Graham ve ark., 1992; Çakmak ve ark., 1999; Alloway, 2004). Tahıl tanelerinin çinko içeriğini yükseltmek, insanlarda beslenme yoluyla ortaya çıkan Zn eksikliğine bağlı sağlık problemlerini azaltmada önemli bir global (küresel) stratejidir.

Buğday, kalıtsal olarak yetersiz düzeyde $\mathrm{Zn}$ içermektedir. Buğday, sindirim sırasında çinkonun emilimini (biyo-yarayışlılığını) kısıtlayan ve anti besin maddesi olarak adlandırılan başta fitik asit olmak üzere; poli-fenoller, tanenler ve lif içeriği bakımından oldukça zengindir. Buğday tohumunda Zn miktarının artmasını kısıtlayan bu faktörlerin azaltılması, artmasını teşvik eden maddelerin (metiyonin, histidin, lisin, sistein, askorbik asit gibi) ise arttırılması gerektiği bildirilmiştir (Welch ve Graham, 2004). Çinkonun buğday tanesine taşınmasında rolü olan fizyolojik mekanizmalar tam olarak tanımlanamamıştır. Tanedeki çinkonun ne kadarının köklerle alındığı, ne kadarının yeşil aksamın diğer kısımlarından taşındı ̆̆ 1 , ne kadarının bayrak yaprağından remobilizasyon yoluyla alındığı gibi konularda araştırmalar devam etmektedir (Hacısalihoğlu ve Kochain, 2003; Waters ve Grusak, 2008).

Son yıllarda yapılan çalışmalarda, tanenin $\mathrm{Zn}$ ve demir (Fe) konsantrasyonunun, azot uygulamasıyla arttırılabileceği ve $\mathrm{Zn}$ ve azot $(\mathrm{N})$ uygulamalarının makarnalık buğdayın tane $\mathrm{Zn}$ konsantrasyonunun arttırılmasında sinerjik etki yaptığı belirtilmiştir (Kutman ve ark., 2010; Shi ve ark., 2010). Azot beslenme statülerinin etkilediği birçok fiziksel ve moleküler mekanizmalardan dolayı, yiyeceklerin $\mathrm{Zn}$ ve $\mathrm{Fe}$ bakımından zenginleştirilmelerinde, bitkilerin $\mathrm{N}$ beslenmesinin en önemli kompenent olduğunu gösterilmektedir (Çakmak ve ark., 2010).

\section{2. Çinkonun Köklerle Alımı ve Yeşil Aksama Taşınması}

Buğday tür ve genotipleri arasında tanede $\mathrm{Zn}$ birikimi bakımından farklar olduğu yapılan çalışmalarla gösterilmiştir. Buna göre, çinko noksanlığına karşı en dayanıklı türün çavdar olduğu; bunu tritikale, arpa, ekmeklik buğday, yulaf ve makarnalık buğdayın izlediği belirtilmiştir (Çakmak ve ark., 1997; Ekiz ve ark., 1998). Çinkonun buğday tanesine taşınmasında rolü olan fizyolojik mekanizmalar tam olarak tanımlanamamıştır. Yapraklarda biriken fotoasimilantların, tane ve meyveye gönderilmesi, doğal yaşlanma sırasında (senesens) generatif dönemde gerçekleşen fizyolojik bir olaydır (Marschner, 1995). Doğal yaşlanma sırasında (senesens) besin asimilasyonu yerini besin remobilizasyonuna birakmakta ve artan miktarlarda besin (amino asitler, basit şekerler, mineral besin elementleri) taneye taşınmaktadır (Feller ve Fischer, 1994; Marschner, 1995). Zhao ve ark. (1999) tarafindan yapılan çalışmalarda, buğday tanesinde bulunan $\mathrm{N}$ ve fosfor (P)'un \% 70-80'i ve kükürt (S)'ün \% 40-50'sinin yeşil aksamdan remobilizasyon yoluyla geldiğini ifade etmektedir. Başka bir çalışmada da genotiplere göre değişen, tanedeki azotun \% 80-89'luk kısmı remobilizasyon ile taşındığ $\breve{b}$ belirtilmiştir (Kichey ve ark., 2007). Senesens sirasinda gövde ve yapraklardan taneye taşınan amino asitler; embriyo, aleuron ve endospermde tane proteinlerinin (albumin, gliadin, glutenin, globulin) sentezinde kullanılmakta, basit şekerler ise endospermde nişasta formunda (Lasztity, 1996; Barneix, 2007) depolanmaktadır.

Biyolojik sistemde $\mathrm{Zn}$ ve protein arasında çok yakın ilişki vardır. Bütün metaller içerisinde $\mathrm{Zn}$ katalizör faaliyetleri ve yapısal bütünlük oluşturmak için en fazla proteine ihtiyaç duyan metaldir. Tane proteinleri, depolama kapasitesini artırarak çinkonun depolanmasına katkıda bulunmaktadır. $\mathrm{Bu}$ hipotez birçok araştırmada belirtildiği gibi tane proteinleri ile tane çinkosu arasındaki (aynı şekilde Fe için de) yüksek pozitif korelasyon ile desteklenmektedir (Morgounov ve ark., 2007; Peleg ve ark., 2008). Yapılan moleküler çalışmalarla, senesens ve tane protein konsantrasyonunun, tanede $\mathrm{Zn}$ birikimi ile ilişkili olduğu gösterilmiştir. Tanedeki Zn ile $\mathrm{N}$ arasındaki yakın ilişki, tetraploid buğdayın 6B kromozomunun kısa kolunda bulunan Gpc-B1 lokusunda yapılan detay çalışmalarla belirlenmiş 
ve bu ilişkinin tanenin protein konsantrasyonu üzerinde etkili olduğu bildirilmiştir. Gpc-Bl lokusu yaşlanmayı teşvik etmesi nedeniyle, bu lokusun mikro besin elementlerinin ve azotun (amino asitler) taneye taşınmasında rol oynadığ 1 düşünülmektedir (Distelfeld ve ark., 2007). Deckard ve ark. (1996)'na göre 6B kromozom hattının yüksek protein konsantrasyonu muhtemelen kökler tarafindan $\mathrm{N}$ alımındaki artışlara ya da taneye artan düzeyde $\mathrm{N}$ taşınımıyla ilişkilidir.

Kade ve ark. (2005) yaptıkları çalışmada, GpcBla allele geninin, tane gelişimi ve olgunlaşma boyunca yarayışlı azotun yapraklardan taneye taşınmasında sorumlu olduğunu belirtmişlerdir. 6B kromozomunun kisa kolunda bulunan Gpc-B1 lokusunda lokalize olan NAM-BI geni; N, Fe ve çinkonun remobilizasyonu ve bu elementlerin tanedeki konsantrasyonlarına katkıda bulunur (Distelfeld ve ark., 2007; Waters ve ark., 2009). NAC (NAM, ATAF1/2, CUC2) transkripsiyon faktörle kodlanan bu gen (NAM-B1), olgunlaşmayı ve besin elementlerinin $(\mathrm{N}, \mathrm{Fe}$ ve $\mathrm{Zn)}$ yeşil aksamdan taneye taşınmasını hızlandırmaktadır (Uauy ve ark., 2006a, 2006b). Buğday genomları üç NAM geni içermekte, fakat modern buğday çeşitleri fonksiyonel olamayan NAM-B1 alleleni taşımaktadır. Bunun olgunlaşmayı geciktirdiği ve tanede düşük protein; $\mathrm{Fe}$ ve $\mathrm{Zn}$ konsantrasyonuna neden olduğu belirtilmiştir. $\mathrm{Bu}$ genlerin tane verimini etkileyip etkilemediği bilinmemektedir (Çakmak, 2008). Tanedeki protein, $\mathrm{Zn}$ ve $\mathrm{Fe}$ konsantrasyonu arasındaki ilişki NAM genin bir genotip üzerinde birden fazla karakteri etkileme (pleiotropic effect) yeteneğinden kaynaklanmış olabileceği düşünülmüştür.

Bununla birlikte diğer bir görüş; bitkinin yaşlanmasının gecikmesi aynı zamanda taneye $\mathrm{Zn}$ birikimini arttırabilir. Bitkiye yüksek dozda $\mathrm{N}$ uygulaması yaşlanmayı geciktirir ve tane dolum periyodunu uzatır (Yang ve Zhang, 2006). Bu nedenle, uzatılmış tane dolum dönemi içerisinde Zn alımı, tane Zn birikimine katkı sağlayabilir.

Buğdayda ksilem iletim demetlerinin tane ile bağlantısı olmadığı için, tüm mineral ve organik maddeler floem kanalı ile taneye taşınmaktadır (Welch, 1986; Pearson ve ark., 1995). Floem $\mathrm{pH}$ 'sının ( $\mathrm{pH}=7.5-8.0)$ yüksek olmasından dolayı çinkonun serbest iyon formunda bulunması ve taşınması mümkün olmamakta ve taneye taşınan çinkonun organik ligandlarla şelat oluşturması gerekmektedir (Marschner, 1995).

Son yıllarda yürütülen çalışmalarda, çinkonun taneye taşınmasında amino asitlerin (özellikle kükürt içeren-aminoasitlerin) önemli rolü olabileceği belirtilmiştir (Dudev ve Lim, 2003; Haydon ve Cobbett, 2007; Torrance ve ark., 2008). Çinkonun rizosferden taneye taşınmasında (tanede $\mathrm{Zn}$ birikiminde oldukça önemli olan) çeşitli fiziksel mekanizmalar (Örneğin; köklerle alım, kökten yeşil aksama taşınma ve remobilizasyon gibi) etkilidir. Çinko ve $\mathrm{Fe}$ katyonlarının rizosferden taneye taşınması, çeşitli proteinler ve amino asit ve peptidleri içeren azotlu bileşiklere bağlı olabilir. Taşıyıcı proteinler, örneğin $\mathrm{Zn}$ düzenleyici taşıyıcılar ve Fe düzenleyici taşıyıcılar (ZIP) gibi proteinler, Sarı Stripe like (YSL) taşıyıcılar ve ağır metal ATPase (HMA, heavymetal-associated domain) ailesi proteinleri; kök alımı, ksilemde yüklenme ve ksilemden boşaltılma, ksilemden floeme değişim, floeme yüklenme ve floemden boşaltılma ve tanede $\mathrm{Zn}$ ve Fe biriktirme kapasitesinin, bitkinin $\mathrm{N}$ beslenmesi durumundan etkilendiği ve bu yolla tanenin $\mathrm{Zn}$ ve Fe derişimi üzerinde etkili olabileceği tartışılmıştır (Curie ve ark., 2009; Palmer ve Guerinot, 2009). Von Wiren ve ark. (1999) Zn ve demirin floemde taşınmada, nicotianamine ile şelatlanmış olabileceğini belirtmiştir. Methionin'den sentezlenen nicotianamine, sadece mugineic asit benzeri fitosideroforların öncü molekülü değildir; aynı zamanda $\mathrm{Fe}$ ve çinkonun floemde taşınması ve tanede depolanmasinda rol almaktadır (Waters ve ark., 2006).

Takahashi ve ark. (2003) transgenik tütün bitkisi kullanarak yaptığı bir çalışmada, nicotianaminin (NA) olasılıkla bir spesifik transporter proteini aracılığıyla, demirin (ve çinkonun) genç yapraklara ve tohumlara taşınımında kritik bir rol oynadığını göstermişlerdir. Nicotianaminin tane gibi gelişmekte olan organlardaki metal-bağımlı proteinlerin regülasyonunu etkilediği kabul edilmektedir. Fitosideroforlar, $\mathrm{Fe}$ ve $\mathrm{Zn}$ içeren metallerin hem alımı hem de translokasyonunu sağlar (Marschner ve Romheld, 1994). Hint kenevirindeki gibi Fe taşıyan proteinler (ITP) gibi proteinler, metal translokasyonuna katkıda bulunabilirler (Kruger ve ark., 2002). Bitkilerin N beslenme statüleri, proteinlerin aktiviteleri ve miktarına bağlı olarak $\mathrm{Zn}$ ve demirin taneye taşınması, retranslokasyonu ve depolanmasını etkileyebilir. Fitosideroforlardan, örneğin Deoxymugineic asit, Zn translokasyonuna katkıda bulunmaktadır (Suzuki ve ark., 2008). Benzer şekilde, bitkilere demirin alımında ve taşınmasında Fe-deoxymugineic asit etkili olmaktadır (Alam ve ark., 2005; Tsukamoto ve ark., 2009). Yüksek N uygulamasının demirin alınımı, yeniden taşınması ve taneye yerleşmesi üzerine olan pozitif etkisi daha önce tanımlanan $\mathrm{Zn}$ mekanizması gibi açıklanabilinir, çünkü bitkideki $\mathrm{Zn}$ ve demirin 
taşınmasında görev yapan şelatörler ve taşıyıcılar aynı veya benzerdirler (Haydon ve Cobbett, 2007).

Kutman (2010)' ’n yürüttüğü çalışmada, $\operatorname{artan} N$ uygulamasinin tohumun $\mathrm{Zn}$ ve $\mathrm{Fe}$ konsantrasyonlarını \% 100 'e varan oranlarda arttırdığını, ancak azotun bu etkisinin yetersiz $\mathrm{Zn}$ uygulaması koşullarında kaybolduğunu; buna karşın, yüksek $\mathrm{N}$ ve $\mathrm{Zn}$ uygulamalarının kombinasyonun ise sinerjik sonuçlar doğurduğunu belirtmişlerdir. Yüksek $\mathrm{Zn}$ varlığında, artan $\mathrm{N}$ uygulaması yeşil aksamın $\mathrm{Zn}$ ve Fe içeriklerini $\%$ 300'e kadar arttırmıştır. Ayrıca, artan N gübrelemesi, çinkonun remobilizasyonunu \% 240, demirin remobilizasyonunu ise \% 70 oranında arttırmıştır. Azot beslenmesinin iyileştirilmesi, Zn ve $\mathrm{Fe}$ derișimlerini sadece tohumun tamamında değil, buğday tohumunun en yaygın tüketilen bölümü olan endosperminde $\mathrm{Zn}$ ve $\mathrm{Fe}$ konsantrasyonlarını yükseltmiştir.

Kutman ve ark. (2011)'nın yürüttükleri diğer bir çalışmada, artan $\mathrm{N}$ uygulamaları tüm tanenin $\mathrm{Zn}$ ve $\mathrm{Fe}$ konsantrasyonlarını önemli şekilde etkilemiştir. Artan Zn ve artan N uygulaması, tüm tanenin $\mathrm{Zn}$ konsantrasyonunu $\% \quad 50 \quad$ ve endospermin $\mathrm{Zn}$ konsantrasyonunu $\% \quad 80$ arttırmıştır. Yapraktan $\mathrm{Zn}$ uygulamasına bağlı olarak, yüksek $\mathrm{N}$ uygulaması, endospermin $\mathrm{Fe}$ konsantrasyonunu \% 100 arttırmıştır.

Erenoğlu ve ark. (2011), besin çözeltisi ortamında yetiştirilen buğday bitkisinin $\mathrm{N}$ beslenme düzeyleri arttırıldığında, çinkonun kökler tarafından alımı, yeşil aksama taşınması ve yeşil aksamda mobilizasyonunun arttığını belirtmişlerdir. $\mathrm{Bu}$ etkinin, buğday tanesinde artan $\mathrm{N}$ ile tane protein içeriğinin artması ve artan protein içeriğinin de Zn bağlanması için önemli olacağ ark., 2010).

Öztürk ve ark. (2011) yürüttükleri çalışmalarda, tane Zn birikimi ile ilişkili fizyolojik mekanizmalardan "kök absorbsiyon" mekanizmasının öne çıktığını belirtmişlerdir. Ayrıca ilgili araştırıcılar, bitkilerin $\mathrm{N}$ ve $\mathrm{S}$ beslenmesinin iyileştirilmesi ile $\mathrm{Zn}$ alımı ve mobilizasyonunun da artış gösterdiğini belirtmişler ve tanedeki $\mathrm{Zn}$ birikiminin arttırılmasında dengeli $\mathrm{N}$ ve $\mathrm{S}$ gübrelemesinin önemli rol oynadığını belirtmişlerdir.

Barut (2012) tarafindan tarla ve sera koşullarında yürütülen denemelerden elde edilen sonuçlara göre; topraktan $\mathrm{Zn}$ ve $\mathrm{N}$ uygulamaları ile yapraktan $\mathrm{Zn}$ uygulamalarının, tane $\mathrm{Zn}$ konsantrasyonunu arttırdığ 1 bulunmuştur. Uygulamalar, tane $\mathrm{N}$ ve $\mathrm{Fe}$ konsantrasyonu üzerinde de etkili olmuştur. Bitki için ortama yeterince Zn sağlandığı zaman, hem topraktan hem de yapraktan $\mathrm{N}$ uygulaması ile tanenin $\mathrm{Zn}$ konsantrasyonu artmıştır. Sera koşullarında yürütülen denemelerde, yeterli çinko uygulaması ile yüksek dozda $\mathrm{N}$ uygulamasının, $\mathrm{Zn}$ ve demirin vejetatif dokudan alınımı ve remobilize olmasina katkısı olmuştur. Elde edilen bu bulgular, bitkinin $\mathrm{N}$ ve $\mathrm{Zn}$ beslenmesinin, tane $\mathrm{Zn}$ ve $\mathrm{Fe}$ konsantrasyonu üzerinde önemli bir unsur olduğunu göstermektedir.

Tanede farklı oranlarda $\mathrm{Zn}$ ve Fe birikiminde, protein içeriğinde, kompozisyonunda ve ekmek yapma kalitesinde bitkilerin $\mathrm{N}$ ve $\mathrm{S}$ ile beslenme rejiminin önemli düzeyde etkili olduğu bildirilmiştir (Lerner ve ark., 2006). Verim, protein konsantrasyonu ve protein kalitesi, dengeli $\mathrm{N}$ ve $\mathrm{S}$ beslenmesi gerektirmektedir. Buğdayın $\mathrm{S}$ ihtiyacı azota göre azdır. Çevresel önlemlerle atmosferik $\mathrm{S}$ girişinin engellenmesi, kükürtlü gübrelerin pahalı olması ve tüketiminin azalması, $\mathrm{S}$ içeren azotlu ve fosforlu gübrelerin kullanım oranlarının azalması, aşırı azotlu gübre kullanımı ve verim potansiyeli yüksek çeşitlerin 1slah edilmesi gibi faktörler; toprak ve bitkide $\mathrm{S}$ eksikliğinin giderek yaygınlaşmasına neden olmaktadır. Kükürt eksikliğinde protein olmayan azotlu bileşikler birikmekte (asparagine, glutamine), $\mathrm{S}$ içeren amino asitlerin (sistein, methionine) sentezi ve tanedeki birikimleri azalmaktadır (Zhao ve ark., 1999; Granvogl ve ark., 2007). Çinkonun floem yoluyla taneye taşınabilmesi için, $\mathrm{S}$ içeren amino asitlerle ligand oluşturması gerekmektedir (Dudev ve Lim, 2003; Haydon ve Cobbett, 2007). Yetersiz kükürt, tahıl ürünlerinin, verim, kalite ve protein içeriği bakımından gerçek potansiyellerine ulaşmasına engel olabilir. Ayrıca, yetersiz kükürt, uygulanan azotun randımanlı kullanılmasını engelleyebilir (Sahota, 2006).

Azot ve kükürtle beslenme düzeyinin iyileşmesi yalnızca verim değil, kalite açısından da oldukça önemlidir. Azot ve kükürt, proteinlerin temel bileşenleridir ve bu nedenle $\mathrm{N}$ ve $\mathrm{S}$ arasındaki bir dengenin buğdayın ekmeklik kalitesinde oldukça önemli olduğu belirtilmiştir (Randall ve Wrigley, 1986). Kükürt, yalnızca azot kullanımı ve protein kalitesini etkilememekte, aynı zamanda pişme kalitesinde önemli bir rol oynamaktadır (Ryant ve Hrivna, 2004). Tahıl ürünlerinde $\mathrm{S}$ eksikliği, yalnızca bitki büyümesi ve verim üzerine değil, aynı zamanda ürünlerin zayıf kaliteye sahip olmasında sinırlayıcı bir faktör olmaktadır. Çünkü kükürt; sistein, methionine, koenzimler, thioredoxine ve sulfolipidler gibi birçok ana bileşiklerin yapısında yer alır. Kükürt uygulamasının, amino asit kompozisyonunu; özellikle kükürt içeren sistein ve methionine oranlarını değiştirdiği belirtilmiştir (Singh, 2003). 
Kükürt eksikliğinde protein sentezinde önemli azalmalar olurken, bitkide çözünür organik azot ve nitrat konsantrasyonunda artışlar olduğu saptanmıştır (Marschner, 1995). Çinkonun floem yoluyla taneye taşınabilmesi için, $\mathrm{S}$ içeren amino asitlerle ligand oluşturması gerekmektedir (Haydon ve Cobbett, 2007; Torrance ve ark., 2008). Bu nedenle özellikle senesens döneminde taneye $\mathrm{Zn}$ taşınmasının sınırlanmaması için yeterli miktarlarda $\mathrm{Zn}$ taşıyıcı ligandların (örneğin, Samino asitler) bulunması gerekmektedir.

\section{Sonuc ve Öneriler}

Mikro besin elementi eksiklikleri arasında, $\mathrm{Zn}$ ve $\mathrm{Fe}$ eksiklikleri en yaygın olanlarıdır. Son dönemlerde yapılan araştırmalara ait bulgular $\mathrm{Zn}$ ve vitamin A eksikliğinin dünya çapında çocuklar arasında gözlemlenen en ciddi besin noksanlıkları olduğunu ortaya koymuştur. $\mathrm{Bu}$ beslenme sorunları 5 yaş altı çocuklarda ölümlerin en önemli nedeni olarak gösterilmiştir (Black ve ark., 2008).

Azot ve $\mathrm{S}$ beslenmesinin buğdayın verim ve kalite parametreleri üzerine etkisi önemlidir. Azot ve kükürt, proteinlerin temel bileşenleridir ve bu nedenle $\mathrm{N}$ ve $\mathrm{S}$ arasındaki bir dengenin buğdayın ekmeklik kalitesinde oldukça önemli olduğu belirtilmiştir. Son dönemlerde yapılan araştırmalarda, Türkiye'de farklı bölgelerde, tarla koşullarında, $\mathrm{N}$ ve $\mathrm{S}$ uygulamasının buğdayda verim ve kalite üzerine etkisini gösterir çalışmalar sınırlıdır. Tarla koşullarında bu tür çalışmaların detaylı bir şekilde araştırılması gerekmektedir. Genel olarak değerlendirildiğinde, yürütülen araştırmalar, tanenin $\mathrm{Zn}$ ve Fe konsantrasyonunun arttırılabilmesi için bitkinin $\mathrm{N}$ ve $\mathrm{Zn}$ beslenmesinin iyileştirilmesi konularının ön plana çıktığını ve bu durumun insan beslenmesi açısından da önemli olduğunu ortaya koymaktadır. Ayrıca, tanenin Zn ve Fe içeriğinin yükseltilmesi konuları agronomik ve genetik yönden detaylı değerlendirilmelidir.

\section{Kaynaklar}

Alam, S., Kamei, S., Kawai, S., 2005. Effectiveness of phytosiderophore in absorption and translocation of 59Iron in barley in the presence of plant-borne, synthetic, and microbial chelators. Journal of plant nutrition, 28(10): 1709-1722.

Alloway, B.J., 2004. Zinc in Soils and Crop Nutrition. IZA Publications. International Zinc Association, Brussels, pp. 1-116.

Barneix, A.J., 2007. Physiology and biochemistry of source-regulated protein accumulation in the wheat grain. Journal of plant physiology, 164(5): 581-590.

Barut, H., 2012. Farklı doz ve zamanlarda uygulanan çinko ve azotun buğdayda tane çinko konsantrasyonu üzerine etkisi. Doktora tezi,
Çukurova Üniversitesi Ziraat Fakültesi, Toprak Bilimi ve Bitki Besleme Bölümü, Adana.

Black, R.E., Lindsay, H.A., Bhutta, Z.A., Caulfield, L.E., De Onnis, M., Ezzati, M., Mathers, C., Rivera, J., 2008. Maternal and child undernutrition: Global and regional exposures and health consequences. Lancet, 371(9608): 243-260.

Curie, C., Cassin, G., Couch, D., Divol, F., Higuchi, K., Jean, M.L., Misson, J., Schikora, A., Czernic, P., Mari, S., 2009. Metal movement within the plant: contribution of nicotianamine and yellow stripe 1like transporters. Annals of Botany, 103(1): 1-11.

Çakmak, İ., 2008. Enrichment of cereal grains with zinc: Agronomic or genetic biofortification? Plant and Soil, 302(1-2): 1-17.

Çakmak, İ., Kalaycı, M., Ekiz, H., Braun, H.J., Yılmaz, A., 1999. Zinc deficiency as an actual problem in plant and human nutrition in Turkey: A NATOScience for Stability Project. Field Crops Research, 60(1): 175-188

Çakmak, İ., Pfeiffer, W.H., Mcclafferty, B., 2010. Biofortification of durum wheat with zinc and iron. Cereal Chemistry, 87(1): 10-20.

Çakmak, İ., Torun, B., Erenoğlu, B., Öztürk, L., Marschner, H., Kalaycı, M., Ekiz, H., Yılmaz, A., 1997. Morphological and physiological differences in the response of cereals to zinc deficiency. In: Wheat Prospects for Global Improvement, Springer Netherlands, pp. 427-435.

Deckard, E.L., Joppa, L.R., Hammond, J.J., Hareland, G.A., 1996. Grain protein determinants of the Langdon durum- diccoides chromosome substitution lines. Crop Science, 36(6): 1513-1516.

Distelfeld, A., Çakmak, İ., Peleg, Z., Öztürk, L., Yazıcı, A.M., Budak, H., Fahima, T., 2007. Multiple QTLeffects of wheat Gpc-B1 locus on grain protein and micronutrient concentrations. Physiologia Plantarum, 129(3): 635-643.

Dudev, T., Lim, C., 2003. Principles governing Mg, Ca, and $\mathrm{Zn}$ binding and selectivity in proteins. Chemical Reviews, 103(3): 773-788.

Ekiz, H., Yılmaz, A., Gültekin, I., Bağcı, S.A., Torun, B., Çakmak, İ., 1998. Konya yöresinde çinko noksanlığı üzerine yürütülen araştırmalar ve sağlanan gelişmeler. I. Ulusal Çinko Kongresi, 1216 Mayıs, Eskişehir, s. 115-121.

Erdal, I., Yılmaz, A., Taban, S., Eker, S., Çakmak, İ., 2002. Phytic acid and phosphorus concentrations in seeds of wheat cultivars grown with and without zinc fertilization. Journal of Plant Nutrition, 25(1): 113-127.

Erenoğlu, E.B., Kutman, U.B., Ceylan, Y., Yıldız, B., Çakmak, İ., 2011. Improved nitrogen nutrition enhances root uptake, root-to-shoot translocation and remobilization of zinc $\left({ }^{65} \mathrm{Zn}\right)$ in wheat. New Phytologist, 189(2): 438-448.

Feller, U., Fischer, A., 1994. Nitrogen metabolism in senescing leaves.Critical Reviews in Plant Sciences, 13(3): 241-273. 
Graham, R.D., Ascher, J.S., Hynes, S.C., 1992. Selecting zinc-efficient cereal genotypes for soils of low zinc status. Plant and Soil, 146(1-2): 241-250.

Granvogl, M., Wieser, H., Koehler, P., Von Tucher, S., Schieberle, P., 2007. Influence of sulfur fertilization on the amounts of free amino acids in wheat. Correlation with baking properties as well as with 3aminopropionamide and acrylamide generation during baking. Journal of Agricultural and Food Chemistry, 55(10): 4271-4277.

Hacısalihoğlu, G., Kochian, L.V., 2003. How do some plants tolerate low levels of soil zinc? Mechanisms of zinc efficiency in crop plants. New Phytologist, 159(2): 341-350.

Haydon, M.J., Cobbett, C.S., 2007. Transporters of ligands for essential metal ions in plants. New Phytologist, 174(3): 499-506.

Kade, M., Barneix, A.J., Olmos, S., Dubcovsky, J., 2005. Nitrojen uptake and remobilization in tetraploid 'Langdon' durum wheat and a recombinant substitution line with the high grain protein gene Gpc- B1. Plant Breeding, 124(4): 343349.

Kichey, T., Hirel, B., Heumez, E., Dubois, F., Le Gouis, J., 2007. In winter wheat (Triticum aestivum L.), post-anthesis nitrogen uptake and remobilisation to the grain correlates with agronomic traits and nitrogen physiological markers. Field Crops Research, 102(1): 22-32.

Kruger, C., Berkowitz, O., Stephan, U.W., Hell, R., 2002. A metal-binding member of the late embryogenesis abundant protein family transports iron in the phloem of Ricinus communis L. Journal of Biological Chemistry, 277(28): 25062-25069.

Kutman, U.B., 2010. Roles of nitrogen and zinc nutrient in biofortification of wheat grain. $\mathrm{PhD}$ Thesis, Sabanci Üniversity, Istanbul.

Kutman, U.B., Yıldız, B., Öztürk, L., Çakmak, İ., 2010. Biofortification of durum wheat with zinc through soil and foliar applications of nitrogen. Cereal Chemistry, 87(1): 1-9.

Kutman, U.B., Yıldız, B., Çakmak, İ., 2011. İmproved nitrogen status enhances zinc and iron concentrations both in the whole grain and the endosperm fraction of wheat. Journal of Cereal Science, 53(1): 118-125.

Lasztity, R., 1996. The Chemistry of Cereal Proteins, Second Edition, CRC Press Inc., Florida.

Lerner, S.E., Seghezzo, M.L., Molfese, E.R., Ponzio, N.R., Cogliatti, M., Rogers, W.J., 2006. N- and Sfertiliser effects on grain composition, industrial quality and end-use in durum wheat. Journal Cereal Science, 44(1): 2-11.

Marschner, H., 1995. Mineral Nutrition of Higher Plants. Second Edition, Academic Press, London.

Marschner, H., Romheld, V., 1994. Strategies of plants for acquisition of iron. Plant and Soil, 165(2): 261274

Morgounov, A., Gomez-Becerra, HF., Abugalieva, A., Dzhunusova, M., Yessimbekova, M., Muminjanov,
H., Zelenskiy, Y., Öztürk, L., Çakmak, İ., 2007. Iron and zinc grain density in common wheat grown in Central Asia. Euphytica, 155(1-2): 193-203.

Öztürk, L., Erenoğlu, B., Kaya, Y., Altıntaş, Z., Haklı, E., Andi, E., Yılmaz, Ö., 2011. Çinko'nun buğday tanesine taşınmasını etkileyen fizyolojik mekanizmaların araştırılması. TÜBİTAK Projesi Sonuç Raporu, Proje No: 108T436.

Palmer, C.M., Guerinot, M.L., 2009. Facing the challenges of $\mathrm{Cu}, \mathrm{Fe}$ and $\mathrm{Zn}$ homeostasis in plants. Nature Chemical Biology, 5(5): 333-340.

Pearson, J.N., Rengel, Z., Jenner, C.F., Graham, R.D., 1995. Transport of zinc and manganese to developing wheat grains. Physiologia Plantarum, 95(3): 449-455.

Peleg, Z., Saranga, Y., Yazıcı, A., Fahima, T., Öztürk, L., Çakmak, İ., 2008. Grain zinc, iron and protein concentrations and zinc-efficiency in wild emmer wheat under contrasting irrigation regimes. Plant and Soil, 306(1-2): 57-67.

Randall, P.J., Wrigley, C.W., 1986. Effects of sulfur supply on the yield, composition and quality of grain from cereals, oilseeds, and legumes. Advances in Cereal Science and Technology, 8: 171-206.

Ryant, P., Hřivna, L., 2004. The effect of sulphur fertilisation on yield and technological parameters of wheat grain. Annales Universitatis Mariae CurieSklodowska, Sectio E, 59(4): 1669-1678.

Sahota, T.S., 2006. Importance of Sulphur in Crop Production. Northwest Link, September, pp. 10-12.

Shi, R., Zhang, Y., Chen, X., Sun, Q., Zhang, F., Romheld, V., Zou ,C., 2010. Influence of Long term nitrogen fertilization on micronutrient density in grain of winter wheat (Triticum aestivum L.). Journal of Cereal Science, 51(1): 165-170.

Singh, B.R., 2003. Sulfur and crop quality-agronomical strategies for crop improvement. Abstracts of COST Action 829 Meetings, Braunschweig, May 15-18, Germany, pp. 35-36.

Suzuki, M., Tsukamato, T., Inoue, H., Watanabe, S., Matsuhashi, S., Takahashi, M., Nakanishi, H., Mori, S., Nishizawa, N.K., 2008. Deoxymugineic acid increases $\mathrm{Zn}$ translocation in $\mathrm{Zn}$-deficienct rice plants. Plant Molecular Biology, 66(6): 609-617.

Takahashi, M., Terada, Y., Nakai, I., Nakanishi, H., Yoshimura, E., Mori, S., Nishizawa, N.K., 2003. Role of nicotianamine in the intracellular delivery of metals and plant reproductive development. The Plant Cell, 15(6): 1263-1280.

Torrance, J.W., Macarthur, M.W., Thornton, J.M., 2008. Evolution of binding sites for zinc and calcium ions playing structural roles. Proteins-Structure, Function and Bioinformatics, 71(2): 813-830.

Tsukamoto, T., Nakanishi, H., Uchida, H., Watanabe, S., Matsuhashi, S., Mori S., Nishizawa, N.K., 2009. Fe52 translocation in barley as monitored by a positron-emitting tracer imaging system (Petis): Evidence for the direct translocation of $\mathrm{Fe}$ from roots to young leaves via phloem. Plant Cell Physiology, 50(1): 48-57. 
Uauy, C., Brevis, J.C., Dubcovsky, J., 2006a. The high grain protein content gene Gpc-B1 accelerates senescence and has pleiotropic effects on protein content in wheat. Journal of Experimental Botany, 57(11): 2785-2794.

Uauy, C., Distelfeld, A., Fahima, T., Blechl, A., Dubcovsky, J., 2006b. A NAC gene regulating senescence improves grain protein, zinc, and iron content in wheat. Science, 314(5803): 1298-1301.

Von Wiren, N., Klair, S., Bansal, S., Briat, J.F., Khodr, H., Shioiri, T., Leigh, R.A., Hider, R.C., 1999. Nicotianamine chelates both Fe-III and Fe-II. Implications for metal transport in plants. Plant Physiology, 119(3): 1107-1114.

Waters, B.M., Chu, H.H., Didonato, R.J., Roberts, L.A., Eisley, R.B., Lahner, B., Salt, D.E., Walker, E.L., 2006. Mutations in arabidopsis yellow stripe-like1 and yellow stripe-like 3 reveal their roles in metal ion homeostasis and loading of metal ions in seeds. Plant Physiology, 141(4): 1446-1458.

Waters, B.M., Grusak, M.A., 2008. Whole-plant mineral partitioning throughout the life cycle in Arabidopsis thaliana ecotypes Columbia, Landsberg erecta, Cape Verde Islands, and the mutant line ysllysl3. New Phytologist, 177(2): 389-405.

Waters, B.M., Uauy, C., Dubcovsky, J., Grusak, M.A., 2009. Wheat (Triticum aestivum) proteins regulate the translocation of iron, zinc, and nitrogen compounds from vegetative tissues to grain. Journal of Experimental Botany, 60(15): 4263-4274.

Welch, R.M., 1986. Effect of nutrient deficiencies on seed production and quality. In: B. Tinker, A. Lauchli (Eds), Advances in Plant Nutrition. Praeger Scientific, New York, pp. 205-247.

Welch, R.M., Graham, R.D., 2004. Breeding for micronutrients in staple food crops from a human nutrition perspective. Journal of experimental botany, 55(396): 353-364.

Yang, J., Zhang, J., 2006. Grain filling of cereals under soil drying. New Phytologist, 169(2): 223-236.

Zhao, F.J., Hawkesford, M.J., McGrath, S.P., 1999. Sulphur assimilation and effects on yield and quality of wheat. Journal Cereal Science, 30(1): 1-17. 